\title{
Skin hyperpigmentation and its treatment with herbs: an alternative method
}

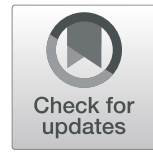

\author{
Prity Rathee ${ }^{1}$, Sunil Kumar ${ }^{1,2^{*}}$, Dinesh Kumar ${ }^{1}$, Beena Kumari ${ }^{2}$ and Savita S. Yadav ${ }^{3}$
}

\begin{abstract}
Background: With an increasing number of patients, those who are facing a lot of skin-related complaints, often referred to as skin of pigmentation patients, are on the rise. Among all the most common complaints in patients with skin of color is hyperpigmentation. So, there is need of herbal formulation for treatment of hyperpigmentation.

Main body: This review article addresses the different types of hyperpigmentation, causes, and its treatment with herbs for the management of the skin hyperpigmentation. As uneven pigmentation of skin or hyperpigmentation is a common skin condition, which occurs when the skin produces more melanin. This can make spots or patches of skin appear darker than surrounding areas. Some forms of hyperpigmentation with post-inflammatory, melasma, and sun spots are more likely to affect areas of face, arms, and legs due to sun exposure and injury. Although the availability of multiple treatments for the condition which leads to some adverse effects, hyperpigmentation continues to present skin care management challenges for dermatologists.

Conclusion: Some plants and phytoconstituents, e.g., Azadirachta indica, Glycyrrhiza glabra, Panax ginseng and genistein, ellagic acids, quercetin, are very useful in herbal cosmetic as anti-hyperpigmentry agents in cosmetic industries. Some of flavonoids and triterpenoids present in plants also show their effect as antioxidant and skin whitening agents. It is expected that this review will compile and improve the existing knowledge on the potential utilization of herbs for the treatment of skin hyperpigmentation.
\end{abstract}

Keywords: Melanin, Hyperpigmentation, Tyrosinase, Age spot, Melasma

\section{Background}

Skin hyperpigmentation is a disorder in which patches of skin become darker in color than the normal surrounding skin. This occurs when melanin is overproduced in certain spots on the skin. Melanin is an important pigment in skin hyperpigmentation which is produced by the process called melanogenesis. Increased melanin pigment in epithelial cell is called melanosis. Epidermal melanosis is when melanocytes are in normal number but melanin is increased in hyper pigmented skin and dermal melanosis occur when melanin is present within the dermis between

\footnotetext{
* Correspondence: sunilmadhuban@igu.ac.in

${ }^{1}$ Institute of Pharmaceutical Science, Kurukshetra University, Kurukshetra

136119, India

2Department of Pharmaceutical Sciences, Indira Gandhi University, Meerpur, Rewari 122502, India

Full list of author information is available at the end of the article
}

bundles of collagen [1]. Melanocyte cells (one melanocyte is surrounded by approximately 36 keratinocytes) produce two type of melanin pigment, eumelanin (Black or brown) and pheomelanin (yellow reddish) which are responsible for skin, hair, and eyes color in human. There is mainly three type of skin 3 hyper-pigmentation which are melsama [2, 3], postinflammatory hyper pigmentation, and age spot or liver spot [4]. Skin hyper-pigmentation is caused by sun exposure, Addison's disease [5], hormonal imbalance, and vitamin $B_{12}$ [6]. In skin cell, UV radiation produces reactive oxygen species (ROS) which activate the intracellular signaling pathways including mutagen-activated protein kinase. As human keratinocyte exposed to UV-B radiation shows higher p38 mitogen-activated protein kinase (MPAK) activity, which produce pro-inflammatory cytokines such as 
1L-1, cyclooxygenase (cox-2), and TNF- $\alpha$ expression [7]. There are two enzymes responsible for melanin production; one is tyrosinase and the other is dopachrome tatuomerase. Tyrsosinase is a main enzyme in melanin growth and over activity of tyrosinase enzyme causes hyper-pigmentation [8]. Tyrosinase involves amino acid tyrosine which on hydroxylation convert into L-3,4-DOPA that form DOPA-quinine by oxidation which is further oxidized by a free radicalcoupling pathway to form melanin $[9,10]$. The other enzyme dopachrome tatuomerase catalyze the transformation of dopachrome into 5,6-dihydroxyindole-2carboxylic acid (DHICA) [11]. There are many herbs or chemical compound found which has tyrosinase inhibitory properties. Tyrosinase inhibitors demands are increasing on the industrial and clinical scale, so invitro assay and screening technique are also developed for tyrosinase inhibitor and other skin whitening agent [12]. Herbs like Glycyrrhiza glabra, Panax ginseng, Embica officinalis, Azadiracta indica, Curcuma longa [13], etc. have been used for treatment of skin hyperpigmentation as shown in Table 1. Also, phytoconstituents like ellagic acids, quercetin, and some whitening agent like kojic acid [72], arbutin [73], etc. are used for treatment as skin hyperpigmentation.

\section{Main text}

Type of skin hyperpigmentation Post-inflammatory hyperpigmentation

It is the acquired hypermelanosis after the skin inflammation or injury that can occur in all skin types. It may occur due to infections such as dermatophytosis, allergic reactions such as mosquito bites, psoriasis, hypersensitive reactions due to medications, or injury from irritant (Fig. 1a), or cosmetic procedures. However, acne vulgaris (Fig. 1b), atopical dermatitis, and impetigo are very common causes of it. Indeed, post-inflammatory hyperpigmentation (PIH) is mainly common after acne in dark-skinned patients. PIH results from the overproduction of melanin or an irregular dispersion of pigment after inflammation. There may be rise in melanocyte activity which may be stimulated by inflammatory mediators as well as reactive oxygen species. Light to dark brown coloration in epidermal post inflammatory hyperpigmentation, whereas dermal PIH tends to be grey to black coloration [74].

\section{Melasma}

Melasma is an acquired hypermelanosis characterized by asymmetric, brown-colored, irregular, reticulated macules on sun exposed areas of the skin, especially the face (Fig. 1c, d). However, chronic ultraviolet (UV) exposure, female hormone stimulation, and predisposed genetic background have all been proposed to play a role in the development of melasma [74]. It is also noticed that a release of histamine from mast cells in response to UV irradiation has been demonstrated to stimulate melanogenesis, which is mediated by $\mathrm{H} 2$ receptors via protein kinase A activation. Sebocytes have been hypothesized to contribute to the development of melasma. Further studies are needed on the role of sebocytes in the pathogenesis of melasma [75].

Effect of hormone on melasma Hormones play a role in the pathogenesis of melasma, estrogen, and progesterone have an impact in melasma development, because melasma is common in pregnancy, hormonal contraceptive use, estrogen therapy in prostate cancer patients, and conjugate estrogen use in women after menopause. In females, melasma is more frequent than in males. Melasma is an undesirable cutaneous effect of oral contraceptives. Melasma is commonly regarded as a physiological change in skin caused by hormone changes. Estrogens play a major role in both physiological and pathological conditions of the skin, including pigmentation. Estrogen and progesterone biological effects are regulated by their different receptors $[75,76]$.

Therapeutic implications The main method of treating melasma is still topical depigmentants. The most common anti-melanogic agent is hydroquinone, which inhibits the conversion of 1-3,4-dihydroxyphenylalanine to melanin via competitive tyrosinase inhibition, has also raised safety concerns such as exogenous ochronosis, permanent depigmentation, and potential cancer hazards [2]. The following are considered as alternatives to topical agents identified for having depigmenting properties with no adverse effects: resveratrol, azelaic acid, 4-nbutyl resorcinol, niacinamide, kojic acid, and ascorbic acid [75].

\section{Age spot}

The brown spots of the skin are aged marks (Fig. 1e). Skin regions, including the face and the back of the hands, grow primarily on that part of skin, which is often exposed to sunlight [9]. Age spots are brown because of lipofuscin bodies of the basal cells. Lipofuscin is the lysosome lipid and protein mixture in which lipids bind by malondialdehyde to protein fragmentations. Age spots vary in form, scale, color, and degree of protrusion in part of the skin. The skin's age spots are made up of the basal cells that bind to the basement membrane in epidermis. The basal cells are the stem cells responsible for the regeneration and repair of epidermis in new epithelial cells. Basal cells and chemical substances can be damaged by ultraviolet radiation and some injured cells can survive and grow old by 
Table 1 Herbs used for treatment of skin hyperpigmentation

\begin{tabular}{|c|c|c|c|c|c|}
\hline S.No & Herbs & Part used & Mechanism of action & Phytoconstituents & Reference \\
\hline 1 & $\begin{array}{l}\text { Glycyrrhiza glabra } \\
\text { [Fabaceae] }\end{array}$ & Root & $\begin{array}{l}\text { UVB protection } \\
\text { Moisturing agent }\end{array}$ & Glycyrrhizic acid, Glycyrrhizin, Glabridin & {$[14,15]$} \\
\hline 2 & $\begin{array}{l}\text { Vitex negundo } \\
\text { [Verbenaceae] }\end{array}$ & Root & Tyrosinase inhibitory & $\begin{array}{l}\text { Negundin A, [+]-lyoniresinol-3a-O-b-D- } \\
\text { glucoside }\end{array}$ & [16] \\
\hline 3 & $\begin{array}{l}\text { Aloe-barbadensis } \\
\text { [Asphodelaceae] }\end{array}$ & Leaf & $\begin{array}{l}\text { Mosituring agent } \\
\text { Tyrosinase inhibitory }\end{array}$ & Aloesin, 2"-Feruloylaloesin & {$[17,18]$} \\
\hline 4 & $\begin{array}{l}\text { Morus alba } \\
\text { [Moraceae] }\end{array}$ & Fruit & $\begin{array}{l}\text { Tyr. } 7 \text { inhibitor } \\
\text { ROS scavenger }\end{array}$ & $\begin{array}{l}\text { Apigenin, umbelliferone, astragalin, } \\
\text { Moranoline, 1-deoxynojirinmycin, resveratrol }\end{array}$ & {$[15,19]$} \\
\hline 5 & $\begin{array}{l}\text { Panax ginseng } \\
\text { [Araliaceae] }\end{array}$ & Root & $\begin{array}{l}\text { Antioxidant, and skin whitening } \\
\text { Agent }\end{array}$ & Ginsenoside, $\mathrm{p}$-Coumaric acid & {$[20,21]$} \\
\hline 6 & $\begin{array}{l}\text { Gingko } \\
\text { [Ginkgoaceae] }\end{array}$ & Flower & Tyrosinasse inhibitor & Ginkgolide A, bilobalide & {$[13,22]$} \\
\hline 7 & $\begin{array}{l}\text { Azadirachta indica } \\
\text { [Meliaceae] }\end{array}$ & Leaf, Bark & $\begin{array}{l}\text { Antioxidant } \\
\text { Antibactrical }\end{array}$ & $\begin{array}{l}\text { Oleic Acid, Azadirachtin, isomeldenin, nimbin, } \\
\text { nimbinene, 6-desacetyl Inimbinene, } \\
\text { nimbandiol }\end{array}$ & [17] \\
\hline 8 & $\begin{array}{l}\text { Santalum album } \\
\text { [Santalaece] }\end{array}$ & Wood & Antioxidant, zskin whitening property & Alpha- and beta-santalol & {$[23,24]$} \\
\hline 9 & $\begin{array}{l}\text { Muntingia calabura } \\
\text { [Muntigaceae] }\end{array}$ & $\begin{array}{l}\text { Flower, } \\
\text { Leaf, Fruit }\end{array}$ & Antityrosinase and antioxidant activity & Stigmasterol, triglyceride, a-linolenic acid & {$[25,26]$} \\
\hline 10 & $\begin{array}{l}\text { Blumea balsamifera } \\
\text { [Asteraceae] }\end{array}$ & Leaves & $\begin{array}{l}\text { Antityrosinase, lipid peroxidation inhibitory } \\
\text { activities, liver-protective }\end{array}$ & 3-O-7W-Biluteolin, & {$[25,27]$} \\
\hline 11 & $\begin{array}{l}\text { Magnolia officinalis } \\
\text { [Magnoliaceae] }\end{array}$ & Bark & Melanogenesis inhibition & $\begin{array}{l}\text { Magnoloside } I_{a} \text {, crassifolioside, magnoloside } \\
V_{a}\end{array}$ & {$[28,29]$} \\
\hline 12 & $\begin{array}{l}\text { Pueraria } \\
\text { thunbergiana } \\
\text { [Leguminosae] }\end{array}$ & Root & Melanogenesisinhibition & Schaftoside, puerarin, genistin & {$[30,31]$} \\
\hline 13 & $\begin{array}{l}\text { Emblica officinalis } \\
\text { [Phyllanthaceae] }\end{array}$ & Fruit & Antioxidant, skin whitening property & $\begin{array}{l}\text { Quercetin, Kaempferol, Gallic acid, Methyl } \\
\text { gallate, Ellagic acid, Trigallayl glucose, } \\
\text { Phyllantine, Phyllembein }\end{array}$ & {$[32,33]$} \\
\hline 14 & $\begin{array}{l}\text { Curcuma longa } \\
\text { [Zingiberaceae] }\end{array}$ & Root & Antioxidant, skin whitening property & Curcuminoids & [23] \\
\hline 15 & $\begin{array}{l}\text { Camellia sinensis } \\
\text { [Theaceae] }\end{array}$ & Leaves & Antioxidant & $\begin{array}{l}\text { Epigallocatechin gallate, epicatechin, } \\
\text { gallocatechin }\end{array}$ & {$[23,34]$} \\
\hline 16 & $\begin{array}{l}\text { Nelumbo nucifera } \\
\text { Gaertn } \\
\text { [Nelumbonaceae] }\end{array}$ & Flower & Antioxidant, tyrosinaseinhibotry activity & $\begin{array}{l}\text { Pronuciferine, Armepavin, Kaempferol-3-o-glu- } \\
\text { coside, Luteolinglucoside }\end{array}$ & {$[35,36]$} \\
\hline 17 & $\begin{array}{l}\text { Crocus sativus } \\
\text { L.[lridaceae] }\end{array}$ & $\begin{array}{l}\text { Dried } \\
\text { stigmas }\end{array}$ & tyrosinaseinhibotry activity & Crocin, picrocrocin, $\beta$ - carotene, safranal. & {$[37,38]$} \\
\hline 18 & $\begin{array}{l}\text { Hemidesmus } \\
\text { indicus } \\
\text { [Asclepiadaceae] }\end{array}$ & Root & Antioxidant, tyrosinaseinhibotry activity & Hemidesminine, Lupeal, vanillin & {$[39,40]$} \\
\hline 19 & $\begin{array}{l}\text { Vitis vinifera } \\
\text { [Vitaceae] }\end{array}$ & $\begin{array}{l}\text { Seed and } \\
\text { leaf }\end{array}$ & Tyrosinaseinhibotry activity & $\begin{array}{l}\text { Gallic, protocatechuic, vanillic, syringic and } \\
\text { ellagic acids }\end{array}$ & {$[17,41]$} \\
\hline 20 & $\begin{array}{l}\text { Euphorbia supina } \\
\text { [Euphorbiaceae] }\end{array}$ & $\begin{array}{l}\text { Leave, } \\
\text { flowers } \\
\text { and tubers }\end{array}$ & Antioxidant, skin lighting agent & Protocatechuic acid, nodakenin, 3-O-glucoside & {$[42]$} \\
\hline 21 & $\begin{array}{l}\text { Brillantaisia } \\
\text { cicatricose Lindau } \\
\text { [Acanthaceae] }\end{array}$ & Leaves & $\begin{array}{l}\text { Hyperpigmentation, leprosy, vermifuge, emetic, } \\
\text { eczema, snakebite, lactogenic }\end{array}$ & $\begin{array}{l}\text { Alkaloids, glycosides, terpenoids, steroids, } \\
\text { flavonoids, tannins and saponins }\end{array}$ & {$[43,44]$} \\
\hline 22 & $\begin{array}{l}\text { Chenopodium } \\
\text { uganda } \\
\text { [Chenopodiaceae] }\end{array}$ & $\begin{array}{l}\text { Stem, } \\
\text { leaves and } \\
\text { flower }\end{array}$ & Tyrosinase inhibitory & $\begin{array}{l}\text { Phenolics, flavonoids, saponins, and } \\
\text { triterpenoids }\end{array}$ & [44] \\
\hline 23 & $\begin{array}{l}\text { Sesamum } \\
\text { angolense Welw. } \\
\text { [Pedaliaceae] }\end{array}$ & Leaves & hyperpigmentation, dysentery & Terpenoids and steroids & [43] \\
\hline
\end{tabular}


Table 1 Herbs used for treatment of skin hyperpigmentation (Continued)

\begin{tabular}{|c|c|c|c|c|c|}
\hline S.No & Herbs & Part used & Mechanism of action & Phytoconstituents & Reference \\
\hline 24 & $\begin{array}{l}\text { Proteamadiensis } \\
\text { Oliv.[Proteaceae] }\end{array}$ & Root, bark & Skin disease, hyperpigmentation & Terpenoids and steroids & [43] \\
\hline 25 & $\begin{array}{l}\text { Carica papaya } L . \\
\text { [Caricaceae] }\end{array}$ & Leaves & Moisturing agent, antioxidant, & Papain, chymopapain A and B & [45] \\
\hline 26 & $\begin{array}{l}\text { Acacia catechu } \\
\text { [Mimosaceae] }\end{array}$ & Bark & Antioxidant activity, Skin whitening property & Catechin, catechutannic acid. & {$[46]$} \\
\hline 27 & $\begin{array}{l}\text { Arnica Montana } \\
\text { [Asteraceae] }\end{array}$ & Flower & Inhibitor in B16 melanoma cells & $\begin{array}{l}\text { Triterpene, essential oils, fatty acids, thymol, } \\
\text { pseudoguaianolidesesquiterpene lactones }\end{array}$ & [47] \\
\hline 28 & $\begin{array}{l}\text { Artemisia } \\
\text { dracunculus } \\
\text { [Asteraceae] }\end{array}$ & Leaves & inhibit melanocyte-stimulating hormone & Isobutyl and piperidiyl & [48] \\
\hline 29 & $\begin{array}{l}\text { Glycine max } \\
\text { [Fabaceae] }\end{array}$ & Seed & Antioxidant, tyrosinase inhibitory activity & $\begin{array}{l}\text { Kunitz-type trypsin inhibitor and Bowman-Birk } \\
\text { protease inhibitor }\end{array}$ & [49] \\
\hline 30 & $\begin{array}{l}\text { Thymelaea hirsuta } \\
\text { [Thymelaeaceae] }\end{array}$ & $\begin{array}{l}\text { Leaves, } \\
\text { Stem and } \\
\text { flower }\end{array}$ & Antioxidant property, antimelanogenesis effect & Genkwadaphnin, gnidicin & {$[50]$} \\
\hline 31 & $\begin{array}{l}\text { Betula pendula } \\
\text { [Betulaceae] }\end{array}$ & Bark, leaves & tyrosinase inhibitory activity & $\begin{array}{l}\text { Phenolics, flavonoids, tannins, saponins, } \\
\text { glycosides, sterols and terpene derivatives }\end{array}$ & [51] \\
\hline 32 & $\begin{array}{l}\text { Caesalpinia sappan } \\
\text { [Fabaceae] }\end{array}$ & Wood & $\begin{array}{l}\text { Inhibit melanogenesis and cellular tyrosinase } \\
\text { activity }\end{array}$ & Homoisoflavanone, sappanone A & {$[52]$} \\
\hline 33 & $\begin{array}{l}\text { Callicarpa } \\
\text { longissima } \\
\text { [Lamiaceae] }\end{array}$ & Leaves & Inhibits melanin production & & [53] \\
\hline 34 & $\begin{array}{l}\text { Carthamus } \\
\text { tinctorius } L \text {. } \\
\text { [Asteraceae] }\end{array}$ & Seeds & Melanogenesis inhibitory activity & $\begin{array}{l}\text { Essential oils contains palmitic acid, } \\
\text { palmitoleic acid, margaric acid, margaroleic } \\
\text { acid }\end{array}$ & {$[54,55]$} \\
\hline 35 & $\begin{array}{l}\text { Coccoloba uvifera } \\
\text { [Polygonaceae] }\end{array}$ & & $\begin{array}{l}\text { Antioxidant and anti-tyrosinase activities, inhib- } \\
\text { ited the production of IL-1a, TNF-a and a-MSH } \\
\text { in melanocytes }\end{array}$ & $\begin{array}{l}\text { Titratable acid } \\
\text { Ascorbic acid }\end{array}$ & {$[56,57]$} \\
\hline 36 & $\begin{array}{l}\text { Colocasia } \\
\text { antiquorum } \\
\text { [Araceae] }\end{array}$ & $\begin{array}{l}\text { Root and } \\
\text { bark }\end{array}$ & Inhibits the melanogenesis & Colocasinol A & {$[58]$} \\
\hline 37 & $\begin{array}{l}\text { Crataegus azarolus } \\
\text { L. [Rosaceae] }\end{array}$ & Leaves & Effect on B16F10 melanoma cells & vitexin-200-O-rhamnoside & [59] \\
\hline 38 & $\begin{array}{l}\text { Juniperus chinensis } \\
\text { L. [Cupressaceae] }\end{array}$ & Fruit & Inhibition of tyrosinase and melanogenesis & Amentoflavone-7-O-D-glucoside & [60] \\
\hline 39 & $\begin{array}{l}\text { Glechoma } \\
\text { hederacea L. } \\
\text { [Lamiaceae] }\end{array}$ & Stem & $\begin{array}{l}\text { Reduced the cellular melanin content and } \\
\text { tyrosinase activity }\end{array}$ & $\begin{array}{l}\text { Germacrene D } \\
\text { Ursolicacid, oleanic acid }\end{array}$ & {$[61,62]$} \\
\hline 40 & $\begin{array}{l}\text { Garcinia livingstonei } \\
T \text { [Clusiaceae] }\end{array}$ & Bark & Inhibit melanin production & $\begin{array}{l}\text { Amentoflavone } \\
\text { 3ßhydroxyeupha-5,22-diene } \\
\text { O-methylfukugetin } \\
\text { Morelloflavone } \\
\text { Volkensiflavone }\end{array}$ & {$[63,64]$} \\
\hline 41 & $\begin{array}{l}\text { Viola odorata } \\
\text { [Violaceae] }\end{array}$ & Leaves & Anti-melanogenic activity & Vitamin C, methyl salicyte & {$[65,66]$} \\
\hline 42 & $\begin{array}{l}\text { Passiflora edulis } \\
\text { [Passifloraceae] }\end{array}$ & Seed & Inhibits melanogenesis & Piceatannol & [67] \\
\hline 43 & $\begin{array}{l}\text { Stewartia } \\
\text { pseudocamellia } \\
\text { [Theaceae] }\end{array}$ & $\begin{array}{l}\text { Bark and } \\
\text { fruit }\end{array}$ & anti-melanogenic activity & $\begin{array}{l}\text { deoxystewartianol-40 -O-arabinoglucoside } \\
\text { stewartianol-3-O-glucoside }\end{array}$ & [68] \\
\hline 44 & $\begin{array}{l}\text { Cyperus rotundus } \\
\text { [Cyperaceae] }\end{array}$ & Rhizomes & $\begin{array}{l}\text { TRPV1 Channel Inhibition and ORAI1Channel } \\
\text { Inhibition. }\end{array}$ & Valencene camphene & [69] \\
\hline 45 & $\begin{array}{l}\text { Cudrania } \\
\text { tricuspidata } \\
\text { [Moraceae] }\end{array}$ & Fruit & Inhibition of L-DOPA Auto-Oxidation & Flaniostatin & {$[70,71]$} \\
\hline
\end{tabular}




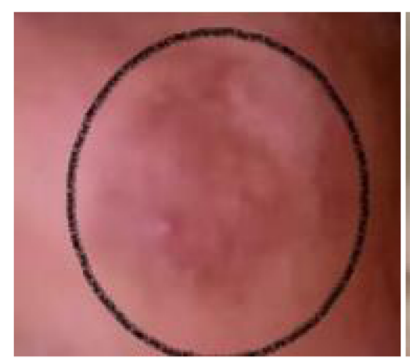

[a]

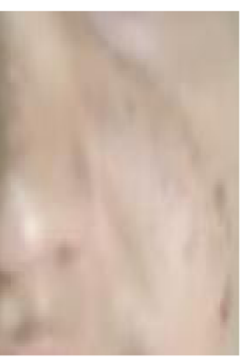

[b]

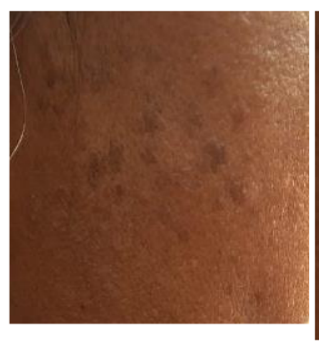

[c]

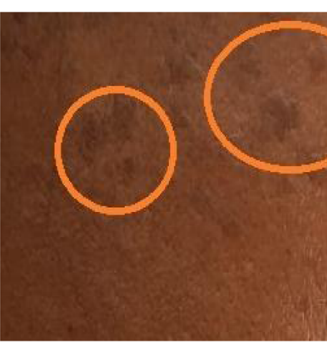

[d]

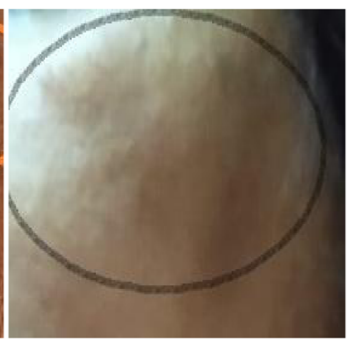

[e]

Fig. 1 Symptoms of skin hyperpigmentation. a Post-inflammatory hyperpigmentation. b Acne produced PIH. c Melsama on face. d Melsama spot. e Age spots on face

misrepairs [77]. Age spot are treated by some skin lighting agents like kojic acid [78].

An aged cell has two effects on a tissue, i.e., reduced neighborhood cell productivity in resolving environmental changes and enhanced damage fragility; and decreased local tissue repair performance. The adjacent cells in an old cell are thus at increased risk of injury and misrepairs. Through this process, an aged cell causes neighboring cells to age [77].

\section{Causes of hyperpigmentation}

Hyper pigmentation is caused by many factors. These may be exogenous and endogenous factor like endocrinologic factor: Addison's disease, Cushing's syndrome, Nelson syndrome, Pheochromocytoma, Carcinoid, Acromegaly, Hyperthyroidism, Acanthosis nigricans, Diabetes. Nutritional factor: Kwashiorkor, Vitamin $\mathrm{B}_{12}$ deficiency [5, 79], Folic acid deficiency, Niacin deficiency, Tryptophan deficiency, Vitamin A deficiency. Melasma is an undesirable skin effect on contraceptive use hormonal [76].

\section{Treatment skin hyperpigmentation by herbs}

In addition to photosafety, there are several medications and treatments to treat hyperpigmentation of the skin of darker skin patients safely and efficiently with some adverse reactions. So, herbs and phytoconstituents are better choice for treatment for skin hyperpigmentation. Some herbs with their mechanism of action for treatment of skin hyperpigmentation are given in Table 1. Hydroquinone, azelaic acid, kojic acid, liquoric extract, retinoids, etc., and treatments like chemexfoliation and laser therapy may be effective on their own properties, or in combination with other drugs [78, 80].

The possible mechanisms of actions by which herbs are used for the treatment of skin hyper pigmentation are namely tyrosinase inhibitory, antioxidant, and skin whitening effects.

\section{Tyrosinase inhibitory effect}

Tyrosinase is a copper-containing enzyme which performs various functions, glycosylated, and found exclusively in melanocytes [81]. It catalyzes conversion of Ltyrosine into L-DOPA which further converted into dopaquinone then dopachrom e[82]. Dopachrome polymerizes to form melanin. Inhibition of tyrosinase enzyme inhibit the melanin production which help to remove the skin hyperpigmentation. Extract of herbal drugs like licorice, Aloe vera, Vitex negundo, Morus alba, and many other drugs are used for inhibition of tyrosinase activity.

Tyrosinase inhibitory effects were calculated by the formula:

$$
\begin{aligned}
& \text { Percentage inhibitory effect } \\
& \begin{array}{l}
=[(\text { Control-Control blank })-(\text { Test-Test blank }) \\
\quad \times 100 /(\text { Control-Control blank })]
\end{array}
\end{aligned}
$$

\section{Antioxidant}

Antioxidants are substances that used to neutralize reactive oxygen species to prevent (for preventing) cells and tissues from oxidative damage. The cutaneous antioxidant system includes enzymatic and non-enzymatic substances. Some enzymatic antioxidants like vitamin E, vitamin $\mathrm{C}$, resveratrol, and lipoic acids. These molecules perform removal of free radicals; neutralization of singlet oxygen in the cell membrane; prevent lipid peroxidation, oxidative and mutagenic action to DNA inhibition; and repair of endogenous antioxidant systems [83]. $\mathrm{IC}_{50}$ for resveratrol was $57.05 \mu \mathrm{g} / \mathrm{mL}$, which demonstrated a great tyrosinase inhibitory potency. But analog of kojic acid shows the most powerful tyrosinase inhibitor [ $\mathrm{IC}_{50}$ $=28.66 \mu \mathrm{g} / \mathrm{mL}$ ], two times more active than resveratrol [84]. Some herbs also show antioxidant effect which are used for the treatment of skin hyperpigmentation are Asphodelus microcarpus [42], Euphorbia supine [85], and Panax ginseng [42]. 


\section{Skin whitening drugs}

Potency of skin whitening agents is due to phenolic component present in the herbs. Arbutin is a natural occurring tyrosinase inhibitor which has skin whitening property with $\mathrm{IC}_{50}$ value of $3.0 \mathrm{mM}$ in HEMn cells [81]. The most commonly used chemical agents are hydroquinone $[\mathrm{HQ}]$, arbutin, kojic acid, liquid nitrogen, laser treatment, chemical skinning, and super natural dermabrasion [28]. Also, ascorbic acid and its products and there are many of herbs or herbal extract used as skin whitening agents are Syzygium aromaticum, Magnolia officinalis, and Holarrhena antidysentrica.

\section{Glycyrrhiza glabra}

Glycyrrhiza glabra extracts play a large role on the skin mainly as a result of its antioxidant activity, especially its strong antioxidant glycyrrhizin, triterpene saponins, and flavonoids. The main attributes are skin whitening, skin depigmentation, lightening of skin, anti-aging, antierythemic, emollient, anti-acne, and photoprotective effects [86]. Gabridin is present in the hydrophobic part of the root extract of Glycyrrhiza and it can reduce tyrosinase activity in culture on melanocytes and inhibit UVB induction [86].

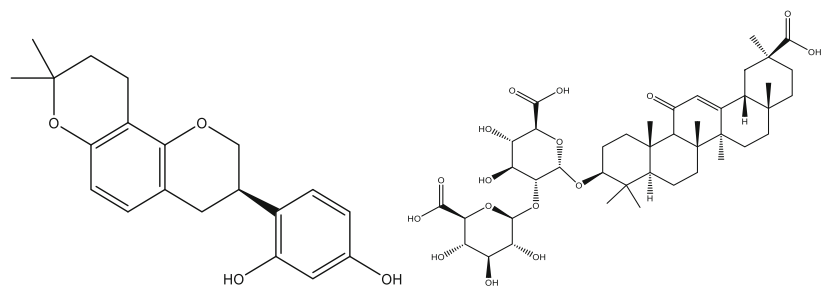

Glabridin

Glycyrrhizin

The extract of licorice inhibits the tyrosinase activity by inhibiting oxidation of L-DOPA to an $\mathrm{IC}_{50}$ value of $53 \mu \mathrm{g} / \mathrm{mL}$. Glabridin content has highest inhibition activity on tyrosinase. The highest inhibitory activity was reported on the first oxidation of tyrosine with $\mathrm{IC}_{50}$ value of $0.9 \mu \mathrm{g} / \mathrm{mL}$ [87].

\section{Vitex negundo}

A poultice of this plant is used for the diagnosis of hyperpigmentation as melasma or ephelides by local cosmetic practitioners. Negundin contains lactone functionally at $\mathrm{C}-2$ position with potent $\mathrm{IC}_{50}$ value of $10.06 \mathrm{mM}$ against tyrosinase enzyme [16]. Vitex negundo is used as skin whitening agent, tyrosinase inhibitor, and inhibit the synthesis of post inflammatory pigmentation [88]. Vitex negundo contains a number of chemical constituents, one of them is negundin A.

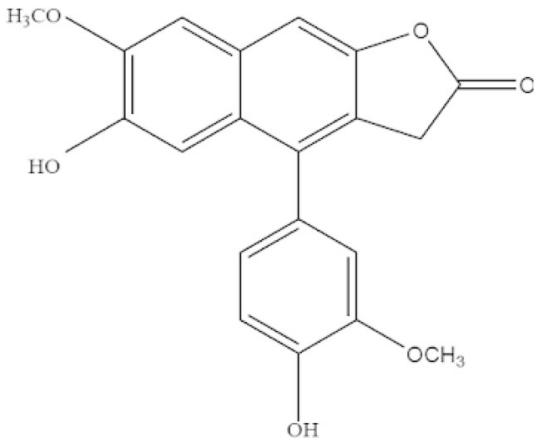

Negundin A

\section{Aloe}

The leaf gel is used as a cure for minor burns and sunburns [7] and Aloe vera gel mainly has antifungal, antiinflammatory, and hepatoprotective potential [89]. The isolates of Aloe vera are barbaloin, aloesin, aglycone of aloenin, 2"'-O-feruloyl aloesin, isoaloeresin $\mathrm{D}$, and aloe resin $\mathrm{E}$ shows potent tyrosinase inhibitory properties. Lyophilized gel shows IC50 $=10.53$ and $6.08 \mathrm{mg} \mathrm{mL}^{-1}$ is for methanolic extract. Aloesin shows highest inhibition value than other molecules extracted form aloe [90].<smiles>CC(=O)Cc1cc(=O)c2c(C)cc(O)c([C@@H]3O[C@H](CO)[C@@H](O)[C@H](O)[C@H]3O)c2o1</smiles>

aloesin

\section{Morus alba}

Flavonoids present in Morus alba extract shows antioxidant and tyrosinase-inhibiting properties. Tyrosinaseinhibiting activity of mulberry extract is comparable with HQ and kojic acid [29]. Oxyresveratrol and Mulberroside-A derived from $M$. alba root which strongly inhibit the monophenolase production and inhibit mushroom tyrosinase activity in melanin synthesis [44]. They have properties of fever reduction, liver protection, and blood pressure lowering. The polyphenols in the leaves have properties for depigmentation [86]. Mulberroside $\mathrm{F}$ have $51.6 \%$ inhibition at $1 \mu \mathrm{g} / \mathrm{mL}$ concentration on $0.29 \mu \mathrm{g} / \mathrm{mL} \mathrm{IC}_{50}$ value [91]. 


\section{Panax ginseng}

Panax ginseng is a herb containing various therapeutically active ginsenosides. P-Coumaric acid isolated from Panax ginseng fresh leaves was used to inhibit L-tyrosine oxidation catalyzed by mushroom tyrosinase. The Panax ginseng berry isolates are Floralginsenoside [FGA], Ginsenoside [GRd], and Ginsenoside $\operatorname{Re}$ [GRe].

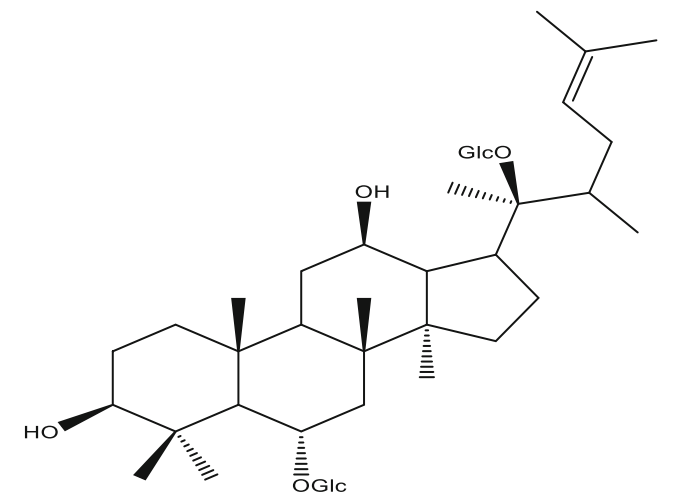

\section{Ginsenoside Re [GRe]}

Of these 3, floralginsenoside [FGA] has been observed to have a powerful inhibitory effect on melanogenesis by means of reduced expression of the microphthalmic-associated factor [3]. Ginseng's importance lies in its many pharmacological roles, such as anticancer activity, as well as shows activity like antioxidant, aging, antistress, and anti-fatigue. Due to the free radical activity of DPPH, the potent antioxidant activity of PgAuNPs has been observed. Panax ginseng leaves also have skin whitening, skinprotective and moisture retention properties $[13,21$, 22 ]. Extract of panax ginseng shows $3.65 \mathrm{mM} \mathrm{IC}_{50}$ value [92].

\section{Gingko biloba}

Ginkgo biloba is a member of the Ginkgoaceae family. The G. biloba extract EGb 761, which contains, most of it, quercetin and Kaempferol derivatives, and terpens [6\%] from tree leaves, containing flavone glycosides [33\%] which has shown capacity to minimize sunburn cells in mice from ultraviolet B (UVB) [93]. Gingko shows anti-inflammatory, anti-vasculature, antioxidant, and tyrosinase properties [8]. Gingko is used to treat various medical problems such as poor circulation of the blood, hypertension, poor memory, and depression [93]. The water extract of Gingko biloba inhibit $50 \%$ of tyrosinase activity at $2.25 \mathrm{mg} /$ $\mathrm{mL} \mathrm{IC}_{50}$. Also, ethanol and ethanol-ether mixture extract shows $50 \%$ inhibitory activity at $\mathrm{IC}_{50}$ value 75 and $0.32 \mathrm{mg} / \mathrm{Ml}$ respectively [94].

\section{Azadirachta indica}

Azadirachta indica shows activity against tyrosinase enzyme and also shows antioxidant and antibacterial properties [95]. It contains isomeldenin, nimbin, nimbinene, 6-desacetyllnimbinene, nimbandiol, and Azadirachtin.

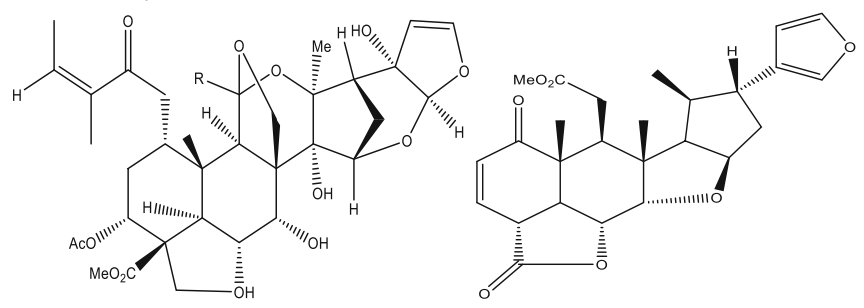

Azadirachtin

Nimbolide

\section{Santalum album}

Sandalwood has many medicinal properties like antiinflammatory, antiphlogistic, antiseptic, antispasmodic, carminative, diuretic, emollient, hypotensive, memory booster, sedative, etc. [96]. Sandalwood oil has protecting, smoothening, moisturizing, hydrating, and skin antiwrinkling properties. The oil inhibits the oxidative enzyme 5-lipoxygenase and has DPPH radical scavenging activity [24]. Alpha-santalol is the major ingredient of sandalwood oil. In comparison to kojic acid and arbutin, it is a potent inhibitor of tyrosinase $\left[\mathrm{IC}_{50}=171 \mu \mathrm{g} / \mathrm{mL}\right]$.

\section{Muntingia calabura}

Muntingia calabura extracts are prepared in different solvents such as ethanol, aqueous, hydro-ethanol, petroleum ether using decoction methods with various parts of plant including leaves, flora, and fruits. This results in optimum anti-thyrosinase and antioxidant activity in the leaf extract of Muntingia calabura in hydroethanol [25]. Plant extracts have an inhibitory effect on melanogenesis. The human body's reactive oxygen species increases the damage done to DNA, the melanin biosynthesis, and the melanocyte proliferation. M. calabura leaf hydroethanol shows $94.00 \pm 1.97 \%$ inhibition of tyrosinase enzyme

\section{Blumea balsamifera}

Blumea balsamifera is a medicinal plant that belongs to the Asteraceae family. The leaves are used for certain conditions such as rheumatism and high blood pressure. As part of the plant with different physiological activities, its leaves have attracted attention, including plasmine inhibitory, antifungal, and hepatroproof, antidiabetic, wound cure, angiogenic. In addition, antibacterium, free radical scavenging, inhibitory activity of lipid peroximization, xanthine ojidase inhibition, superoxide scavenging activities, and antityrosinase activity were identified in the methanol extracts of the leaves of 
the plant [97]. Nine flavonoids are isolated from Blumea balsamifera from ethyl acetate extract [25].

\section{Magnolia officinalis}

Magnolia officinalis [Magnoliaceae] has antispasmodic, anticancer, antioxidative, and antidiabetic activities. The extract of plant Magnolia officinalis inhibits melanogenesis by a pre-translational regulation on tyrosinase gene expression. It also exhibits depigmenting activity. The fermented methanol bark extract shows antityrosinase activity and at a conc. of $200 \mu \mathrm{g} / \mathrm{mL}$, it reduces $99.8 \%$ of melanin formation $[98,99]$.

\section{Pueraria thunbergiana}

$P$. thunbergiana root and flower have various medicinal properties. EtOAc-soluble extract fractions were more effective than kojic acid, a whitening agent used for positive control for a $\mathrm{MSH}$-induced melanin synthesis. Tyrosinase specifically affected by the aerial portion of $P$. thunbergiana [30]. Extraction of root have \% inhibition of tyrosinase at 1 $\mathrm{mg} / \mathrm{mL}, 2 \mathrm{mg} / \mathrm{mL}$, and $4 \mathrm{mg} / \mathrm{mL}$ are $10.36 \%, 0.78 \%$, $13.22 \%$, and $3.13 \%$ respectively [100].

\section{Emblica officinalis}

E. officinalis is recognized for its nutritional content. A wide range of chemicals are present, including flavonolglycosides, carbohydrates, mucic acids, amino acids, sesquiterpenoids, alkaloids, flavone glycosidses, phenolic glycosides, phenolic acids, and tannins. E. officinalis fruit juice contains the highest amount of vitamin $C$ and vitamin $\mathrm{E}$ as compared to other fruit juice. The extract could inhibit tyrosinase, by inhibiting microphthalmiaassociated transcription factor (MITF) and Trp-1 gene expression, but under low concentration of the extract treatment would induce Trp-2 gene expression. EPE has higher $\mathrm{IC}_{50}$ than the MPE; emblica fruit shows $\mathrm{IC}_{50}$ $4346.95 \pm 166.23 \mu \mathrm{g} / \mathrm{mL}$. Ethanolic extract has higher antioxidant and anti-melnogenesis effect [101, 102].

\section{Curcuma longa}

Curcuma longa contains some active ingredient which have tyrosinase inhibitory or depigmentry activity like curcumin, demethylcurcumin, and bisdemethyl curcumin. Among these, curcumin has the highest percentage of tyrosinase inhibition [23].<smiles>COc1cc(/C=C/C(=O)CC(=O)/C=C/c2ccc(O)c(OC)c2)ccc1O</smiles>

curcumin
Natural curcuminoides show potent inhibitory activity as compared to synthetic curcumin analog. Curcumin analog has higher tyrosinase activity with compound o-diphenols and m-diphenols than other compound. Tyrosinase activity is inhibited by curcuminoids by inhibiting L-dopa oxidation [103]. Partially purified curcuma longa [PPC] inhibits the level of tyrosinase protein like MITF, TRP1, and also suppress the $\alpha$-MSH stimulated cells. Activation of ERK or PI3k/Akt in signaling pathway by suppressive mechanism of PPC on melanogenesis [104].

\section{Camellia sinensis}

It is commonly known as green tea. It belongs to the Theaceae family. Green tea is made of steamed, dried, rolling leaves to inactivate endogenous polyphenol oxidase [PPO]. The activities of Camellia sinensis, melanin synthesis, and expression of melanogenic enzyme at the protein and mRNA levels in melan-A cells were evaluated by researchers [105]. Green tea contains active ingredients like -[-]-epigallocatechin-3-gallate[EGCG], [-]-epigallocatechin[EGC], [-]-catechin[C], [-]-gallocatechingallate [GCG], and [-]-epicatechingallate [ECG]. EGCG inhibit melanin production in mouse melanoma cells. All active ingredients do not show potent inhibitory activity but EGCG and gallic acid show higher tyrosinase inhibitory activity by cell proliferation. EGCG and GA also inhibit cell proliferation in cell line of K562 [human leukemia cell] and 293T [human embryonic kidney] [106]. Further, $6.2 \%$ of IC50 of methanol extract of seed $[644.93 \pm 1.44 \mu \mathrm{g} / \mathrm{mL}]$. Methanol extract of pericarp shows 12 time stronger $\mathrm{IC}_{50}$ value than the methanol extract of seed which is IC50 $=57.77 \pm 0.34 \mu \mathrm{g} / \mathrm{mL}$ [107].

\section{Nelumbo nucifera Gaertn}

Family of Nelumbo nucifera Gaertn is Nelumbonaceae. Commonly, it is known as Indian lotus. Its seed and leaves extract contain alkaloids, saponine, and phenols which shows antioxidative activity against tissue oxidation. Lotus seed and leaves show protective effects on skin against UVB irradiation, anti-wrinkle effect, and skin whitening effect $[35,108]$.

\section{Crocus sativus $L$}

It is commonly known as saffron belonging to family Iridaceae. The antioxidant activity of extract was $81 \%$ using $70 \%$ ethanol. Crocus sativus decreases the melanin pigment from the skin. Emulsion is use in the cosmetic or medicine preparation to treat skin hyperpigmentation and used as skin whitening agent [40]. Isorhamnetin-3, 49-diglucoside has $55.7 \%$ at $2666.7 \mu \mathrm{m} / \mathrm{mL}$ concentration with $1.84 \mathrm{~mm} \mathrm{IC}_{50}$ [109]. 


\section{Hemidesmus indicus}

It belongs to family Asclepiadaceae and commonly known as Anantmul. H. indicus decreases the monophenols and diphenols activity of tyrosinase by inhibiting Ldopa to dopachrome synthesis in melanin production. Monophenolase activity inhibition by 2-hydroxy-4-methoxybenzaldehyde MBALD was studied with a substratum l-tyrosin e[39]. Hemidesminine, Lupeal, and vanillin are the active constituents which shows antioxidant effect [40].

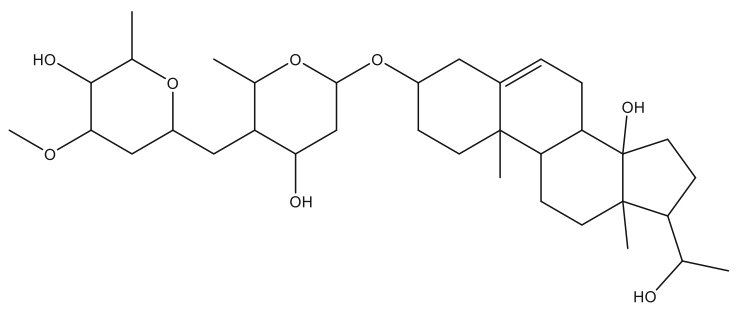

Heminine

\section{Vitis vinifera}

The main active ingredients of which are red vine leaf extract (RVLE), contains many flavonoids. Deionized water was the solvent used in RVLE preparation. The solution RVLE showed the possibility of inhibiting dopachrome formation that can be observed at wavelength of $475 \mathrm{~nm}$ with a spectrophotometer. The bioactive components of RVLE included gallic acid, chlorogenic acid, epicatechin, rutin, and resveratrol. RVLE solution is also used in cosmetic formulations as natural whitening agent [52]. Extract of VVC is more potent then arbutin to inhibit tyrosinase activity and its has 30 훨 $\mathrm{g} \mathrm{mL}^{-1} \mathrm{IC}_{50}$ value [110].

\section{Euphorbia supina}

The ES extract has a non-cytotoxic effect on the proliferation of B16F10 cells. Clear cytotoxicity is observed in B16F10 cells at a concentration of $1000 \mu \mathrm{g} / \mathrm{mL}$. The ES extract showed an occurrence of $93.05 \pm 0.6 \%$ at $200 \mu \mathrm{g} /$ $\mathrm{mL}$ almost equivalent to ascorbic acid. ES extracts had a relatively high ABTS+ radical scavenge activities of 8 and $40 \mu \mathrm{g} / \mathrm{mL}$ [14]; protocatechuic acid, nodakenin, and 3-O-glucoside are the chemical constituent present in the Euphorbia supina [111].

\section{Acacia catechu}

The extract has recorded high tyrosinase inhibition activity at a concentration of $120 \mu \mathrm{g} / \mathrm{ml}$, with an inhibition percentage of 61.58 compared to a positive kojic acid regulation [98.73\% inhibition] at a concentration equivalent to $120 \mu \mathrm{g} / \mathrm{ml}$. Without preservative, A. catechu whitening cream has maintained strong stability for 3 months [46].

\section{Carica papaya}

It contains papain, chymopapain A and B which shows antioxidant activity. It also contains calcium, sugar, fiber, vitamin $\mathrm{C}$, thiamine, riboflavin, niacin, amino acid, carotene, and malic acids. It also includes proteins and fats [45]. It has been found that carica fruit extract is having $87 \%$ of antioxidant activity. The phenolic compounds in papaya fruit contained two major groups. The most important natural antioxidant groups are these phenolic compounds [111].

\section{Arnica montana}

$3 \beta, 16 \beta$-Dihydroxy-21a-hydroperoxy-20[30]-tariaxasten is a compound present in Arnica montana that is found to be 50 times stronger than 4-methoxyphenol, a commonly used depigmenting agent; it inhibited in the melanin biosynthesis, without affecting cells production and much stronger than arbutin as well. At $0.125 \mathrm{mg} / \mathrm{mL}$, Arnica flowers inhibit melanin synthesis in $80 \%$ ethanol extract [47].

\section{Artemisia dracunculus}

Undeca-2E,4E-dien-8,10-dynoic acid isobutylamide and piperidylamide are two active compounds found in Artemisia dracunculus. These compounds inhibit mediated melanin production in B16 cells of mouse melanoma potently by inhabitation of melanocyte-stimulating hormone [-MSH]. Consequently, the cytotoxicity was not related to the inhibitor activity of compounds 1 and 2 against melanin biosynthesis [48].

\section{Thymelaea hirsuta}

$T$. hirsuta extract shows a time-dependent decrease in cytoplasmic accumulation of melanin and do not show any cytotoxicity effect. Genkwadaphnin and gnidicin are the active constituents in the extract of $T$. hirsuta which shows effect against melanin synthesis. By ERK1/2 phosphorylation, melanogenesis effect on B16 cells are decreases. Inhibition of melanin production by downregulation of tyrosinase by Thymelaea hirsuta [112].

\section{Betula pendula}

In addition to metal chelating, Betula pendula is a significant source of strong depigmentants with an effect on tyrosinase to decrease and scavenge properties. Chlorogenic acid, Catechin, p-Coumaric acid, Isoquercitrin, Chrysoeriol, and Quercetin-3-O-glucuronide are the active constituents present in the extract. The power of chain-breaking antioxidants, phenolic compounds, including flavonoids, which scavenge lipid peroxyl radicals, 
Table 2 Phytoconstituents for the treatment of skin hyperpigmentation

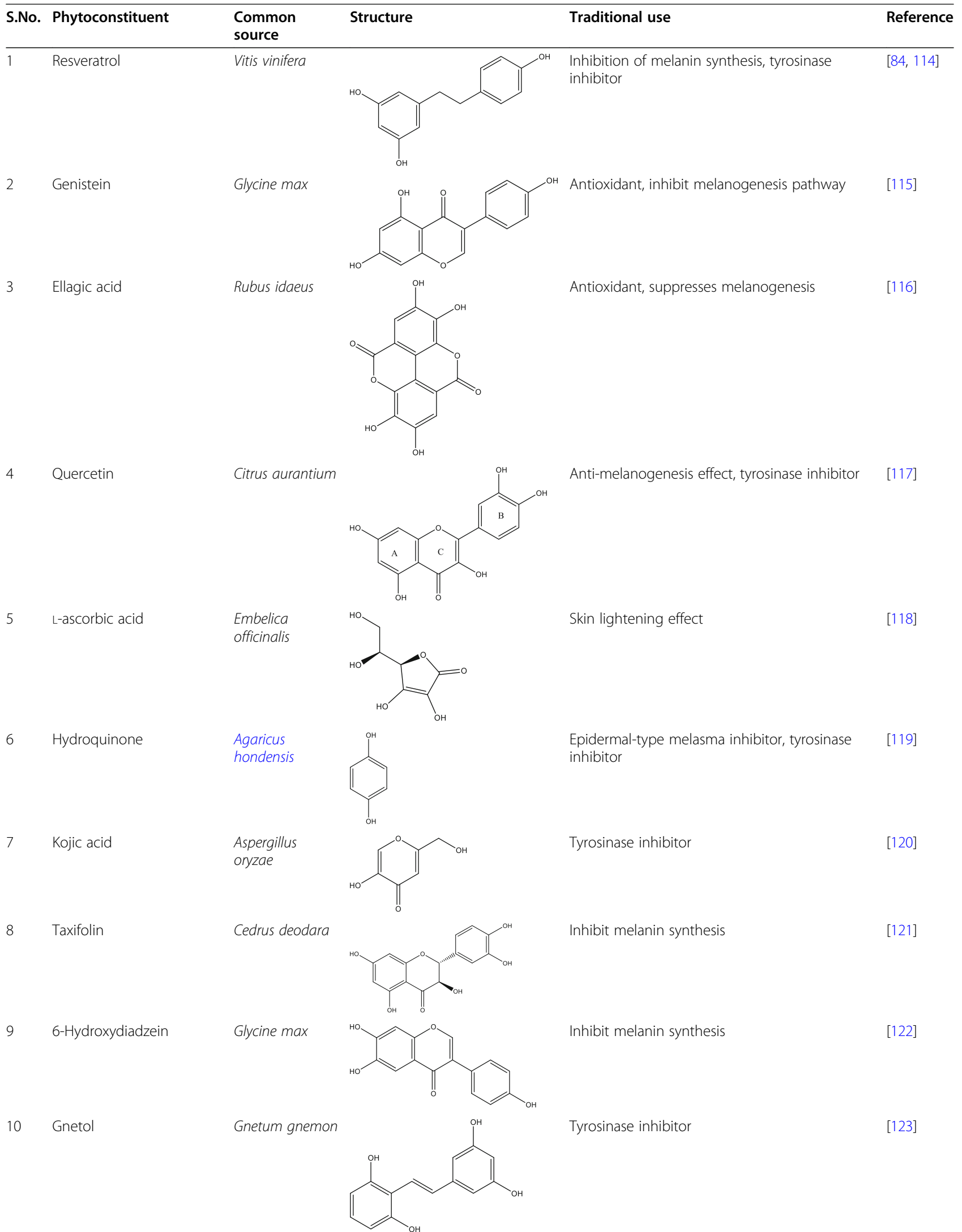


Table 2 Phytoconstituents for the treatment of skin hyperpigmentation (Continued)

\begin{tabular}{|c|c|c|c|c|c|}
\hline S.No. & Phytoconstituent & $\begin{array}{l}\text { Common } \\
\text { source }\end{array}$ & Structure & Traditional use & Reference \\
\hline 11 & $\begin{array}{l}\text { 9-Hydroxy-4- } \\
\text { methoxypsoralen }\end{array}$ & $\begin{array}{l}\text { Angelica } \\
\text { dahurica }\end{array}$ & & Tyrosinase inhibitor & [124] \\
\hline 12 & Kuraridin & $\begin{array}{l}\text { Sophora } \\
\text { flavescens }\end{array}$ & & Tyrosinase inhibitor & [125] \\
\hline 13 & p-Coumaric Acid & $\begin{array}{l}\text { Arachis } \\
\text { hypogaea }\end{array}$ & & Antioxidant, inhibit melanin synthesis & [126] \\
\hline
\end{tabular}

break through chain sequences with the same mechanism as radical hydroxyl scavenging. Then, $30.21 \pm 0.23 \%$ of tyrosinase inhibitory effect were observed at $80 \mu \mathrm{g} /$ $\mathrm{mL}$ concentration on $119.08 \pm 2.04 \mu \mathrm{g} / \mathrm{mL} \mathrm{IC} \mathrm{I}_{50}$ [113].

\section{Caesalpinia sappan}

Homoisoflavanone, sappanone A are isolated from the extract of Caesalpinia sappan. The crude extract has demonstrated highest melanogenesis inhibitory activity in mouse B16 melanoma cells and crude extract of C. sappan has been evaluated in a previous study for antiproliferating activity in B16 melanoma cells. Homoisoflavanones are a small class of oxygen that occur naturally. Sapanone A shows a dose-dependent inhibition of melanogenesis [52].<smiles>O=C1/C(=C/c2ccc(O)c(O)c2)COc2cc(O)ccc21</smiles>

\section{Sapanone A}

\section{Callicarpa longissima}

Callicarpa longissima inhibits the development of melanin by suppressing the MITF [microphthalmia-associated transcription factor] gene expression of the B16F10 mouse melanoma cells. Carnosol is present in the extract of Callicarpa longissimi which has oxidative property and carnosol and carnosic acid are responsible for inhibiting melanin synthesis [53].
Phytoconstituents used for the treatment of skin hyperpigmentation are given in Table 2.

\section{Conclusion}

In this review, we discussed many of herbs and phytoconstituent which are used as tyrosinase inhibitor and also as skin whitening agents. Skin is the most important part of our body. The colour of skin is determined by the presence of melanin in the skin. Melanin is a pigment present in skin which is responsible for the skin color in plants and mammals. When the amount of melanin is increased in the skin, then it causes hyperpigmentation on the skin. Synthesis of melanin depends mainly on tyrosinase enzyme. It convert L-tyrosine in LDOPA and L-DOPA to dopaquinone by which melanin is produced in the epidermis layer of skin and affect the skin color. Plants like Azadiracta indica, Glycyrrhiza glabra, Panax ginseng and genistein, ellagic acids, quercetin, and many other phytoconstituents which are used in herbal cosmetic as anti-hyperpigmentry agents in cosmetic industries. Some of flavonoids and triterpenoids present in these herbs show their effect as antioxidant and skin whitening agents.

\section{Abbreviations}

MITF: Microphthalmia-associated transcription factor; ROS: Reactive oxygen species; MPAK: Mitogen-activated protein kinase; COX: Cyclooxygenase; DHICA: Dihydroxyindole-2-carboxylic acid; HQ: Hydroquinone; PPC: Purified curcuma longa; RVLE: Red vine leaf extract; PPO: Polyphenol oxidase
Acknowledgement Not applicable. 


\section{Authors' contributions}

We declare that this work was done by the authors named in this article: SK conceived and designed the study. PR carried out the literature collection of the data and writing of manuscript. SSY helped in writing of the manuscript. DK and BK assisted in the data analysis and corrected the manuscript. All the authors read and approved the final manuscript.

\section{Funding}

Not applicable.

\section{Availability of data and materials}

All the information in the manuscript has been referred from the included references and is available upon request from the corresponding author.

\section{Declarations}

\section{Ethics approval and consent to participate}

Not applicable.

\section{Consent for publication}

Not applicable.

\section{Competing interests}

The authors declare that they have no competing interests.

\begin{abstract}
Author details
'Institute of Pharmaceutical Science, Kurukshetra University, Kurukshetra 136119, India. ${ }^{2}$ Department of Pharmaceutical Sciences, Indira Gandhi University, Meerpur, Rewari 122502, India. ${ }^{3}$ Department of Pharmaceutical Chemistry, Bharati Vidyapeeth Deemed University, Poona College of Pharmacy Erandwane, Pune 411038, India.
\end{abstract}

\section{Received: 13 January 2021 Accepted: 15 June 2021}

Published online: 02 July 2021

\section{References}

1. Banna H, Hasan N, Lee J, Kim J, Cao J, Lee EH, Moon HR, Chung HY, Yoo JW (2018) In vitro and in vivo evaluation of MHY908-loaded nanostructured lipid carriers for the topical treatment of hyperpigmentation. J Drug Deliv Sci Technol 48:457-465

2. Picardo M, Carrera M (2007) New and experimental treatments of cloasma and other hypermelanoses. Dermatol Clin 25(3):353-362

3. Nieuweboer-Krobotova L (2013) Hyperpigmentation: Types, diagnostics and targeted treatment options. J EurAcad Dermatology Venereol 27(1):2-4

4. Goswami P, Sharma HK (2020) Skin hyperpigmentation disorders and use of herbal extracts: a review. Curr Trends Pharm Res 7(2):81-104

5. Sarkar SB, Sarkar S, Ghosh S, Bandyopadhyay S (2012) Addison 's disease. Contemp Clin Dent 3(4):484-486

6. Kannan R, Ng MJM (2008) Cutaneous lesions and vitamin B12 deficiency: an often-forgotten link. Can Fam Physician 54(4):529-532

7. Afnan Q, Kaiser PJ, Rafiq RA, Nazir LA, Bhushan S, Bhardwaj SC et al (2016) Glycyrrhizic acid prevents ultraviolet-B-induced photodamage: a role for mitogen-activated protein kinases, nuclear factor kappa B and mitochondrial apoptotic pathway. Exp Dermatol 25(6):440-446

8. Mapunya MB, Nikolova RV, Lall N (2012) Melanogenesis and antityrosinase activity of selected South African plants. Evid Based Compl Altern Med 2012:1-6. https://doi.org/10.1155/2012/374017

9. Del Bino S, Duval C, Bernerd F (2018) Clinical and biological characterization of skin pigmentation diversity and its consequences on UV impact. Int J Mol Sci 19(9):2668

10. Wang KH, Lin RD, Hsu FL, Huang YH, Chang HC, Huang CY et al (2006) Cosmetic applications of selected traditional Chinese herbal medicines. J Ethnopharmacol 106(3):353-359

11. Choi SY, Kim S, Hwang JS, Lee BG, Kim H, Kim SY (2004) Benzylamide derivative compound attenuates the ultraviolet B-induced hyperpigmentation in the brownish guinea pig skin. Biochem Pharmacol 67(4):707-715

12. Zolghadri S, Bahrami A, Hassan Khan MT, Munoz-Munoz J, Garcia-Molina F, Garcia-Canovas F et al (2019) A comprehensive review on tyrosinase inhibitors. J Enzyme Inhib Med Chem 34(1):279-309
13. Gediya SK, Mistry RB, Patel UK, Blessy M, Jain HN (2011) Herbal plants: used as a cosmetics. J Nat Prod Plant Resour 1(1):24-32

14. Ebanks JP, Wickett RR, Boissy RE (2009) Mechanisms regulating skin pigmentation: The rise and fall of complexion coloration. Int J Mol Sci 10(9): 4066-4087. https://doi.org/10.3390/ijms10094066

15. Fisk WA, Agbai O, Lev-Tov HA, Sivamani RK (2014) The use of botanically derived agents for hyperpigmentation: a systematic review. J Am Acad Dermatol 70(2):352-365. https://doi.org/10.1016/j.jaad.2013.09.048

16. Azhar-Ul-Haq MA, Khan MTH, Anwar-Ul-Haq KSB, Ahmad A et al (2006) Tyrosinase inhibitory lignans from the methanol extract of the roots of Vitex negundo Linn. and their structure-activity relationship. Phytomedicine 13(4): 255-260. https://doi.org/10.1016/j.phymed.2004.09.001

17. Vaibhav S, Lakshaman K (2012) Tyrosinase Enzyme Inhibitory Activity of selected Indian Herbs. Int J Res Pharmaceut Biomed Sci 3(3):977-982

18. Yagi A, Kanbara T, Morinobu N (1987) Inhibition of mushroom-tyrosinase by Aloe extract. Planta Med 53(6):515-517. https://doi.org/10.1055/s-2006-962 798

19. Grajek K, Wawro A, Kokocha D (2015) Bioactivity of Morus alba Extracts-An overview. Int J Pharm Sci Res 6(8):3110

20. Jiménez-Pérez ZE, Singh P, Kim YJ, Mathiyalagan R, Kim DH, Lee MH, Yang DC (2018) Applications of Panax ginsengleaves-mediated gold nanoparticles in cosmetics relation to antioxidant, moisture retention, and whitening effect on B16BL6 cells. J Ginseng Res 42(3):327-333. https://doi.org/10.1016/ j.jgr.2017.04.003

21. Lee JO, Kim E, Kim JH, Hong YH, Kim HG, Jeong D, Kim J, Kim SH, Park C, Seo DB, Son YJ, Han SY, Cho JY (2018) Antimelanogenesis and skinprotective activities of Panax ginseng calyx ethanol extract. J Ginseng Res 42(3):389-399. https://doi.org/10.1016/j.jgr.2018.02.007

22. Wang $X$, Gong $X$, Zhang $H$, Zhu W, Jiang Z, Shi $Y$ et al (2020) In vitro antiaging activities of ginkgo biloba leaf extract and its chemical constituents. Food Sci Technol 40(2):476-482. https://doi.org/10.1590/fst.02219

23. Mukherjee PK, Biswas R, Sharma A, Banerjee S, Biswas S, Katiyar CK (2018) Validation of medicinal herbs for anti-tyrosinase potential. J Herb Med 14:116. https://doi.org/10.1016/j.hermed.2018.09.002

24. Moy RL, Levenson C (2017) Sandalwood album oil as a botanical therapeutic in dermatology. J Clin Aesthet Dermatol 10(10):34-39

25. Gupta SK, Gautam A, Kumar S (2014) Natural skin whitening agents : a current status. Adv Biol Res (Rennes) 8(6):257-259

26. Ragasa CY, Tan MCS, Chiong ID, Shen CC (2015) Chemical constituents of Muntingia calabura L. Der Pharma Chem 7(5):136-141

27. Ali DMH, Wong KC, Lim PK (2005) Flavonoids from Blumea balsamifera. Fitoterapia 76(1):128-130. https://doi.org/10.1016/j.fitote.2004.10.015

28. Ong MW, Maibach HI (2014) 40 Skin whitening agents. Handbook Cosmetic Sci Technol 9:423

29. Ge L, Zhang W, Zhou G, Ma B, Mo Q, Chen Y et al (2017) Nine phenylethanoid glycosides from Magnolia officinalis var. biloba fruits and their protective effects against free radical-induced oxidative damage. Sci Rep 7:2-13

30. Han EB, Chang BY, Kim DS, Cho HK, Kim SY (2014) Melanogenesis inhibitory effect of aerial part of Pueraria thunbergiana in vitro and in vivo. Arch Dermatol Res 307(1):57-72. https://doi.org/10.1007/s00403-014-1489-z

31. Son E, Yoon JM, An BJ, Lee YM, Cha J, Chi GY et al (2019) Comparison among activities and isoflavonoids from Pueraria thunbergiana aerial parts and root. Molecules 24(5):1-12

32. Mathai RT, Baliga MS, Sup D (2015) Learn more about Emblica officinalis Amla in the prevention of aging use of ayurvedic medicinal plants as immunomodulators in geriatrics indian berries and their active compounds. Academic Press 8:29-35

33. Dasaroju S, Gottumukkala KM (2014) Review Article Current Trends in the Research of. Int J Pharm Sci Rev Res 24(2):150-159

34. Koch W, Zagórska J, Marzec Z, Kukula-Koch W (2019) Applications of tea (Camellia sinensis) and its active constituents in cosmetics. Molecules 24(23):1-28

35. Huang B, Zhu L, Liu S, Li D, Chen Y, Ma B, Wang Y (2013) In vitro and in vivo evaluation of inhibition activity of lotus (Nelumbo nucifera Gaertn.) leaves against ultraviolet B-induced phototoxicity. J Photochem Photobiol B Biol 121:1-5. https://doi.org/10.1016/j.jphotobiol.2013.02.005

36. Panth N, Paudel KR, Karki R (2016) Phytochemical profile and biological activity of Juglans regia. J Integr Med 14(5):359-373. https://doi.org/10.1016/ S2095-4964(16)60274-1

37. Adhikari A, Devkota HP, Takano A, Masuda K, Nakane T, Basnet P, SkalkoBasnet N (2008) Screening of Nepalese crude drugs traditionally used to 
treat hyperpigmentation: in vitro tyrosinase inhibition. Int J Cosmet Sc 30(5):353-360. https://doi.org/10.1111/j.1468-2494.2008.00463.x

38. Akhtar N, Khan HMS, Ashraf S, Mohammad IS, Ali A (2014) Skin depigmentation activity of Crocus Sativus extract cream. Trop J Pharm Res 13(11):1803-1808. https://doi.org/10.4314/tjpr.v13i11.5

39. Kundu A, Mitra A (2014) Evaluating tyrosinase (monophenolase) inhibitory activity from fragrant roots of Hemidesmus indicus for potent use in herbal products. Ind Crop Prod 52:394-399. https://doi.org/10.1016/j.indcrop.2013.1 0.053

40. Chakrabortty S, Choudhary R (2014) Hemidesmus Indicus (Anantmool): rare herb of Chhattisgarh. Ind J Sci Res 4(1):89-93

41. Lin YS, Chen HJ, Huang JP, Lee PC, Tsai CR, Hsu TF et al (2017) Kinetics of tyrosinase inhibitory activity using Vitis Vinifera leaf extracts. Biomed Res Int 2017:5

42. Di Petrillo A, González-Paramás AM, Era B, Medda R, Pintus F, Santos-Buelga C et al (2016) Tyrosinase inhibition and antioxidant properties of Asphodelus microcarpus extracts. BMC Complement Altern Med 16(1):1-9

43. Kamagaju L, Morandini R, Bizuru E, Nyetera P, Nduwayezu JB, Stévigny C et al (2013) Tyrosinase modulation by five Rwandese herbal medicines traditionally used for skin treatment. J Ethnopharmacol 146(3):824-834

44. Kamagaju L, Bizuru E, Minani V, Morandini R, Stévigny C, Ghanem G, Duez P (2013) An ethnobotanical survey of medicinal plants used in Rwanda for voluntary depigmentation. J Ethnopharmacol 150(2):708-717. https://doi. org/10.1016/j.jep.2013.09.031

45. Rodrigo UD, Perera BGK (2018) Important biological activities of papaya peel extracts and their importance in formulation of a low cost fish feed to enhance the skin colour and the healthiness of guppies. Int J Sci Res Publ 8(12):702-708

46. Anurukvorakun O, Boonruang R, Lahpun N (2019) Formulation strategy, stability issues, safety and efficacy evaluations of Acacia catechu whitening cream. Int J Appl Pharm 11(2):91-96

47. Aeda KM, Aitou TN, Mishio KU, Ukuhara TF, Otoyama AM (2007) A novel melanin inhibitor: hydroperoxy traxastane-type triterpene from flowers of Arnica montana. Biol Pharm Bull 30:873-879

48. Yamada M, Nakamura K, Watabe T, Ohno O, Kawagoshi M, Maru N et al (2011) Melanin biosynthesis inhibitors from tarragon Artemisia dracunculus. Biosci Biotechnol Biochem 75(8):1628-1630. https://doi.org/10.1271/bbb.11 0306

49. Menaa F, Menaa A, Tréton J (2013) Polyphenols against skin aging. Polyphenols Hum Heal Dis 1:819-830

50. Amari NO, Bouzouina M, Berkani A, Lotmani B (2014) Phytochemical screening and antioxidant capacity of the aerial parts of Thymelaea hirsuta $L$. Asian Pacific J Trop Dis 4(2):104-109. https://doi.org/10.1016/S2222-1808(14 60324-8

51. Calliste CA, Trouillas P, Allais DP, Simon A, Duroux JL (2001) Free radical scavenging activities measured by electron spin resonance spectroscopy and B16 cell antiproliferative behaviors of seven plants. J Agric Food Chem 49(7):3321-3327. https://doi.org/10.1021/jf010086v

52. Chang T, Chao S, Ding H (2012) Melanogenesis Inhibition by Homoisoflavavone Sappanone A from Caesalpinia sappan. Int J Mol Sci 13(8):10359-10367. https://doi.org/10.3390/ijms130810359

53. Yamahara M, Sugimura K, Kumagai A, Fuchino H (2016) Callicarpa longissima extract, carnosol-rich, potently inhibits melanogenesis in B16F10 melanoma cells. J Nat Med 70(1):28-35. https://doi.org/10.1007/s11418-015-0933-5

54. Oh JSR, An YH, Im HK, Wang JKH (2004) Inhibitory effects of active compounds isolated from safflower (Carthamus tinctorius L.) seeds for melanogenesis. Biol Pharm Bull 27(12):1976-1978

55. Al-snafi AE (2015) The chemical constituents and pharmacological importance of importance of Carthamus Tinctorius - an overview. J Pceutical Bio 5(3):143-166

56. Sanches P, Velazquez C, Eberlin S, Dieamant GC, Claudio L, Stasi D (2008) Effects of Coccoloba uvifera L. on UV-stimulated melanocytes. Photodermatol Photoimmunol Photomed 6:308-313

57. Segura Campos MR, Ruiz Ruiz J, Chel-Guerrero L, Betancur Ancona D (2015) Coccoloba uvifera(L.)(Polygonaceae) fruit: phytochemical screening and potential antioxidant activity. J Chemother 2015:1-9. https://doi.org/10.11 $55 / 2015 / 534954$

58. Kim KH, Moon E, Kim SY, Lee KR (2010) Lignans from the tuber-barks of Colocasia antiquorum var. esculenta and their antimelanogenic activity. J Agric Food Chem 58(8):4779-4785. https://doi.org/10.1021/ jf100323q
59. Bze $M$, Chekir-ghedira $L$ (2015) Compounds isolated from the aerial part of Crataegus azarolus inhibit growth of B16F10 melanoma cells and exert a potent inhibition of the melanin synthesis. Biomed Pharmacother 69:139144

60. Park S, Jegal J, Chung KW, Jung HJ, Noh SG, Chung HY et al (2018) Isolation of tyrosinase and melanogenesis inhibitory flavonoids from Juniperus chinensis fruits. Biosci Biotechnol Biochem 82(12):2041-2048. https://doi. org/10.1080/09168451.2018.1511367

61. Qiao Z, Koizumi Y, Zhang M, Natsui M, Jolina M, Gao L et al (2012) Antimelanogenesis effect of Glechoma hederacea $L$. extract on B16 murine melanoma cells. Biosci Biotechnol Biochem 76(10):1877-1883

62. Aumeeruddy-Elalfi Z, Gurib-Fakim A, Mahomoodally MF (2016) Kinetic studies of tyrosinase inhibitory activity of 19 essential oils extracted from endemic and exotic medicinal plants. South Af J Bot 103:89-94. https://doi. org/10.1016/j.sajb.2015.09.010

63. Mulholland DA, Mwangi EM, Dlova NC, Plant N, Crouch NR, Coombes PH (2013) Non-toxic melanin production inhibitors from Garcinia livingstonei (Clusiaceae). J Ethnopharmacol 149(2):570-575. https://doi.org/10.1016/j. jep.2013.07.023

64. On S, Aminudin NI, Ahmad F, Sirat HM, Taher M (2016) Chemical constituents from stem bark of Garcinia prainiana and their bioactivities. Int J Pharmacogn Phytochem Res 8(5):756-760

65. Rahimi VB, Askari VR, Emami SA, Tayarani-Najaran Z (2017) Anti-melanogenic activity of Viola odorata different extracts on B16F10 murine melanoma cells. Iran J Basic Med Sci 20(3):242-249. https://doi.org/10.22038/ijbms.2017. 8350

66. Mittal P, Gupta V, Goswami M, Thakur N, Bansal P (2015) Phytochemical and pharmacological potential of Viola Odorata. Int J Pharmacogn 2(5):215-220

67. Uzuki TAS, Atagata YOK, To TAI (2010) Extract of passion fruit (Passiflora edulis ) seed containing high amounts of piceatannol inhibits melanogenesis and promotes collagen synthesis. J Agric Food Chem 11: $112-118$

68. Seong Z, Won HKY, Kim J, Oh HSDKS, Cho H (2016) Phenylacylphenol derivatives with anti-melanogenic activity from Stewartia pseudocamellia. Arch Pharm Res 39(5):636-645. https://doi.org/10.1007/ s12272-016-0717-9

69. Nam JH, Lee D (2016) Valencene from the rhizomes of Cyperus rotundus inhibits skin photoaging-related ion channels and UV-induced melanogenesis in B16F10 melanoma cells. J Nat Prod 70(4):1091-1096

70. Hwang J, Lee BM (2007) Inhibitory effects of plant extracts on Tyrosinase, IDOPA oxidation, and melanin synthesis. J Toxicol Environ 70(5):393-407

71. Kang Y, Choi JU, Lee EA, Park HR (2013) Flaniostatin, a new isoflavonoid glycoside isolated from the leaves of Cudrania tricuspidata as a tyrosinase inhibitor. Food Sci Biotechnol 22(5):1-4. https://doi.org/10.1007/s10068-0130236-0

72. Cabanes J, Chazarra S, Garcia Carmona F (1994) Kojic acid, a cosmetic skin whitening agent, is a slow binding inhibitor of catecholase activity of tyrosinase. J Pharm Pharmacol 46(12):982-985

73. Zhu W, Gao J (2008) The use of botanical extracts as topical skin-lightening agents for the improvement of skin pigmentation disorders. J Investig Dermatol Symp Proc 13(1):20-24

74. Lee AY (2014) An updated review of melasma pathogenesis. Dermatologica Sin 32(4):233-239. https://doi.org/10.1016/j.dsi.2014.09.006

75. Kwon SH, Na Jl, Choi JY, Park KC (2019) Melasma: Updates and perspectives. Exp Dermatol 28(6):704-708

76. Mahdalena I, Jusuf NK, Putra IB (2018) Melasma characteristic in hormonal contraceptive acceptors at Kelurahan Mangga Kecamatan Medan Tuntungan, Medan-Indonesia. Bali Med J 7(3):645-649

77. Wang-Michelitsch J, Michelitsch TM (2015) Development of age spots as a result of accumulation of aged cells in aged skin. arXiv Prepr arXiv $1505070121-9$

78. Saeedi M, Eslamifar M, Khezri K (2019) Kojic acid applications in cosmetic and pharmaceutical preparations. Biomed Pharmacother 110:582-593. https://doi.org/10.1016/j.biopha.2018.12.006

79. Cherqaoui R, Husain M, Madduri S, Okolie P, Nunlee-Bland G, Williams J (2013) A Reversible cause of skin hyperpigmentation and postural hypotension. Case Rep Hematol 2013(1):1-5. https://doi.org/10.1155/2013/ 680459

80. Davis EC, Callender VD (2010) A review of the epidemiology, clinical features and treatment options in skin of color. J Clin Aesthet Dermatol 3(7): 20 
81. Balakrishnan KP, Narayanaswamy N, Duraisamy A (2011) Tyrosinase inhibition and anti-oxidant properties of Muntingia calabura extracts: In vitro studies. Int J Pharm Bio Sci 2(1):294-303

82. Shirota S, Miyazaki K, Aiyama R, Ichioka M, Yokokura T (1994) Tyrosinase inhibitors from crude drugs. Biol Pharm Bull 17(2):266-269

83. Addor FAS (2017) Antioxidants in dermatology. An Bras Dermatol 92(3):356362. https://doi.org/10.1590/abd1806-4841.20175697

84. Zimmermann Franco DC, de Carvalho G, Senra G, Rocha PR, Da Silva TR, Da Silva AD, Barbosa Raposo NR (2012) Inhibitory effects of resveratrol analogs on mushroom tyrosinase activity. Molecules 17(10):11816-11825. https://doi. org/10.3390/molecules171011816

85. Kang SH, Jeon YD, Cha JY, Hwang SW, Lee HY, Park M et al (2018) Antioxidant and skin-whitening effects of aerial part of Euphorbia supina Raf. Extract. BMC Complement Altern Med 18(1):4-11

86. Couteau C, Coiffard L (2016) Overview of skin whitening agents: drugs and cosmetic products. Cosmetics 3(3):27. https://doi.org/10.3390/cosmetics303 0027

87. Nerya O, Vaya J, Musa R, Izrael S, Ben-Arie R, Tamir S (2003) Glabrene and isoliquiritigenin as tyrosinase inhibitors from licorice roots. J Agric Food Chem 51(5):1201-1207. https://doi.org/10.1021/jf020935u

88. Smit N, Vicanova J, Pavel S (2009) The hunt for natural skin whitening agents. Int J Mol Sci 10(12):5326-5349. https://doi.org/10.3390/ijms10125326

89. Bean MF, Abramson D (2009) Extraction, purification and identification of Aloe gel from Aloe vera (Aloe barbadensis Miller). Nat Prod Ind J 5(3):111115

90. Gupta SD, Masakapalli SK (2013) Mushroom tyrosinase inhibition activity of Aloe vera L. gel from different germplasms. Chin J Nat Med 11(6):616-620. https://doi.org/10.1016/S1875-5364(13)60071-0

91. Lee SH, Choi SY, Kim H, Hwang JS, Lee BG, Gao JJ, Kim SY (2002) Mulberroside $\mathrm{F}$ isolated from the leaves of Morus alba inhibits melanin biosynthesis. Biol Pharm Bull 25(8):1045-1048. https://doi.org/10.1248/bpb.2 5.1045

92. Parvez S, Kang M, Chung HS, Cho C, Hong MC, Shin MK, Bae H (2006) Survey and mechanism of skin depigmenting and lightening agents. Phytother Res 20(11):921-934. https://doi.org/10.1002/ptr.1954

93. Joshi LS (2015) Herbal cosmetics and cosmeceuticals: an overview. Nat Prod Chem Res 3(2):170

94. Wang Q, Zhong X, Qiu L, Jx Z, Qx C (2008) Inhibitory mechanism of extracts from Ginkgo biolaba sarcotesta on mushroom tyrosinase(J). Guihaia 3:24

95. Chiocchio I, Mandrone M, Sanna C, Maxia A, Tacchini M, Poli F (2018) Screening of a hundred plant extracts as tyrosinase and elastase inhibitors, two enzymatic targets of cosmetic interest. Ind Crop Prod 12:498-505

96. Bhowmik D, Biswas D, Kumar KP (2011) Recent aspect of ethnobotanical application and medicinal properties of traditional Indian Herbs Santalum album. Int J Curr Res 1:21-27

97. Thach BĐ, Vu Q, Dao T, Thi L, Giang L, Nguyen T et al (2017) Inhibitor effect of flavonoid from Blumea Balsamifera leaves extract on melanin synthesis in cultured B16F10 cell line and zebrafish. Eur J Res Med Sci 5(2):31-36

98. Ding HY, Chang TS, Chiang CM, Li SY, Tseng DY (2011) Melanogenesis inhibition by a crude extract of Magnolia officinalis. J Med Plant Res 5(2): 237-244

99. Wu L, Chen C, Cheng C, Dai H, Ai Y, Lin C, Chung Y (2018) Evaluation of tyrosinase inhibitory, antioxidant, antimicrobial, and antiaging activities of Magnolia officinalis extracts after Aspergillus niger fermentation. Biomed Res Int 2018:1-11

100. Lee KT, Kim BJ, Kim JH, Heo MY, Kim HP (1997) Biological screening of 100 plant extracts for cosmetic use (I): inhibitory activities of tyrosinase and DOPA auto-oxidation. Int J Cosmet Sci 19(6):291-298. https://doi.org/1 0.1111/j.1467-2494.1997.tb00193.x

101. Variya BC, Bakrania AK, Patel SS (2016) Emblica officinalis (Amla): a review for its phytochemistry, ethnomedicinal uses and medicinal potentials with respect to molecular mechanisms. Pharmacol Res 11(1):180-200

102. Sripanidkulchai B, Junlatat J (2014) Bioactivities of alcohol based extracts of Phyllanthus emblica branches: antioxidation, antimelanogenesis and antiinflammation. J Nat Med 68(3):615-622. https://doi.org/10.1007/s11418-014-0824-1

103. Du ZY, Jiang YF, Tang ZK, Mo RQ, Xue GH, Lu YJ et al (2011) Antioxidation and tyrosinase inhibition of polyphenolic curcumin analogs. Biosci Biotechnol Biochem 75(12):2351-2358. https://doi.org/10.1271/bbb.110547

104. Jang JY, Lee JH, Jeong SY, Chung KT, Choi YH, Choi BT (2009) Partially purified Curcuma longa inhibits alpha-melanocyte-stimulating hormonestimulated melanogenesis through extracellular signal-regulated kinase or
AKT activation-mediated signalling in B16F10 cells. Exp Dermatol 18(8):689694. https://doi.org/10.1111/j.1600-0625.2009.00857.x

105. Kim YC, Choi SY, Park EY (2015) Anti-melanogenic effects of black, green, and white tea extracts on immortalized melanocytes. J Vet Sci 16(2):135143. https://doi.org/10.4142/jvs.2015.16.2.135

106. Sato K, Toriyama M (2009) Depigmenting effect of catechins. Molecules 14(11):4425-4432. https://doi.org/10.3390/molecules14114425

107. Jo YH, Yuk HG, Lee JH, Kim JC, Kim R, Lee SC (2012) Antioxidant, tyrosinase inhibitory, and acetylcholinesterase inhibitory activities of green tea (Camellia sinensis L.) seed and its pericarp. Food Sci. Biotechnol 21(3):761-768

108. Kim SY, Moon GS (2015) Photoprotective effect of lotus (Nelumbo nucifera Gaertn.) seed tea against UVB irradiation. Prev Nutr Food Sci 20(3):162-168. https://doi.org/10.3746/pnf.2015.20.3.162

109. Li CY, Wu TS (2002) Constituents of the pollen of Crocus sativus L. and their tyrosinase inhibitory activity. Chem Pharm Bull 50(10):1305-1309

110. Park J, Boo YC (2013) Isolation of resveratrol from Vitis viniferae caulis and its potent inhibition of human tyrosinase. Evid. Based Complement Altern 2013:1-10

111. Song Y, Jeong SW, Lee WS, Park S, Kim YH, Kim GS et al (2014) Determination of polyphenol components of Korean prostrate spurge (Euphorbia supina) by using liquid chromatography-tandem mass spectrometry: Overall contribution to antioxidant activity. J Anal Methods Chem 2014:1-8

112. Kawano M, Matsuyama K, Miyamae $Y$, Shinmoto $H$, Kchouk ME, Morio $T$ et al (2007) Antimelanogenesis effect of Tunisian herb Thymelaea hirsuta extract on B16 murine melanoma cells. Exp Dermatol 16(12): 977-984

113. Germanò MP, Cacciola F, Donato P, Dugo P, Certo G, D'Angelo V et al (2012) Betula pendula leaves: polyphenolic characterization and potential innovative use in skin whitening products. Fitoterapia 83(5):877-882. https:// doi.org/10.1016/j.fitote.2012.03.021

114. Pillaiyar T, Manickam M, Namasivayam V (2017) Skin whitening agents: medicinal chemistry perspective of tyrosinase inhibitors. J Enzyme Inhib Med Chem 32(1):403-425. https://doi.org/10.1080/14756366.2016.1256882

115. Zhou Q, Feng C, Ruan Z (2017) Inhibitory effect of a genistein derivative on pigmentation of guinea pig skin. RSC Adv 7(13):7914-7919

116. Konda S, Geria AN, Halder RM (2012) New horizons in treating disorders of hyperpigmentation in skin of color. Semin Cutan Med Surg 31(2):133-139

117. Choi MH, Shin HJ (2016) Anti-melanogenesis effect of quercetin. Cosmetics 3(2): 1-16

118. De Dormael R, Bastien P, Sextius P, Gueniche A, Ye D, Tran C et al (2019) Vitamin $C$ prevents ultraviolet-induced pigmentation in healthy volunteers: Bayesian meta-analysis results from 31 randomized controlled versus vehicle clinical studies. J Clin Aesthet Dermatol 12(2):E53-E59

119. Duarte I, Lazzarini R, Rotter A (2010) Dermatological drugs, topical agents, and cosmetics. Side Eff Drugs Ann 32:295-304. https://doi.org/10.1016/S03 78-6080(10)32014-9

120. Sarkar R, Arora P, GargKv (2013) Cosmeceuticals for hyperpigmentation: what is available? J Cutan Aesthet Surg 6(1):4

121. Liu-Smith F, Meyskens FL (2016) Molecular mechanisms of flavonoids in melanin synthesis and the potential for the prevention and treatment of melanoma. Mol Nutr Food Res 60(6):1264-1274. https:/doi.org/10.1002/mnfr.201500822

122. Goh MJ, Park JS, Bae JH, Kim DH, Kim HK, Na YJ (2012) Effects of orthodihydroxyisoflavone derivatives from Korean fermented soybean paste on melanogenesis in b16 melanom cells and human skin equivalents. Phyther Res 26(8):1107-1112. https://doi.org/10.1002/ptr.3682

123. Uchida R, Ishikawa S, Tomoda H (2014) Inhibition of tyrosinase activity and melanine pigmentation by 2-hydroxytyrosol. Acta Pharm Sin B 4(2):141-145. https://doi.org/10.1016/j.apsb.2013.12.008

124. Chang TS (2009) An updated review of tyrosinase inhibitors. Int J Mol Sci 10(6):2440-2475

125. Lin JW, Chiang HM, Lin YC, Wen KC (2008) Natural products with skinwhitening effects. J Food Drug Anal 16(2):1-10

126. Boo YC (2019) p-coumaric acid as an active ingredient in cosmetics: a review focusing on its antimelanogenic effects. Antioxidants 8:275

\section{Publisher's Note}

Springer Nature remains neutral with regard to jurisdictional claims in published maps and institutional affiliations. 